\title{
Free Trade: Does Myopic Policy Overlook Long-Term Gains?
}

\section{Maryiam Haroon*}

\begin{abstract}
This article analyzes the correlation between trade liberalization and welfare in Pakistan from 1986 to 2015. Using consumption expenditure as a measure of welfare, we estimate the relationship using a vector error correction model. The empirical results show that trade liberalization does not have an immediate correlation with welfare: it takes some time for liberalization policies to enhance welfare. The findings also suggest that trade liberalization can help reduce poverty, decrease inequality and increase enrollment levels in the long run. But in the short run, trade liberalization has led to higher income inequality.
\end{abstract}

Keywords: Welfare, trade liberalization, social indicators, Pakistan.

JEL classification: F13.

\section{Introduction}

Liberalization policies are aimed at achieving global integration through policy choices pertaining to trade and price liberalization, budget restructuring, privatization and social safety nets, among others. Trade liberalization is considered a crucial component of economic integration and has garnered considerable attention in the growth and welfare literature, given that trade policy choices play an important role in determining growth.

Developing countries were generally criticized earlier for adopting import substitution policies. After the formation of the World Trade Organization (WTO), free trade and trade barrier reduction were emphasized. Countries are classified as liberalized economies if (i) their average tariff rate is less than 40 percent, (ii) nontariff barriers cover less than 40 percent of their trade, (iii) the black market exchange rate is not less than 20 percent relative to the official exchange rate, (iv) the state has no monopoly over major exports and (v) the country does not follow a socialist economic system (Sachs \& Warner, 1995).

\footnotetext{
* Assistant Professor, Department of Economics, Lahore School of Economics.
} 
Proponents of trade liberalization argue that it improves growth, enhances economic efficiency and leads to greater equality, thus making it a win-win strategy. Liberalization leads to stronger competition, increases efficiency by ensuring more efficient resource allocation, and helps achieve economies of scale through access to world markets and productivity gains through the adoption of new technologies (Sachs \& Warner, 1995). Open economies are better able to absorb technological advancements generated by scientifically advanced countries, thereby improving their likelihood of growth (Wacziarg \& Welch, 2008).

Some postwar developing countries that initiated policies of trade liberalization and subsequently witnessed considerable growth include Cyprus, Hong King, Malaysia, Mauritius, Singapore and Thailand. Their economic transformation has led many economists to focus on the impact of liberalization on growth (see, for instance, Sachs \& Warner, 1995; Wacziarg \& Welch, 2008; Harrison, 1996; Chatterji, Mohan \& Dastidar, 2014). The story that emerges in the literature is that open economies whether developed or developing - have higher growth rates than closed ones. Their average growth rates also reveal that, among open economies, developing countries have higher growth rates than developed countries (Harrison, 1996; Gries \& Redlin, 2012). Other studies document the relationship between trade liberalization and economic growth for Pakistan (see Din, Ghani \& Siddique, 2003; Siddiqui \& Iqbal, 2005; Yasmin, Jehan \& Chaudhary, 2006).

While trade liberalization enhances growth, its impact on welfare needs to be evaluated, given that it is expected to create winners and losers (Winters \& Martuscelli, 2014). Various factors determine the impact of trade liberalization policy on economic and social welfare, including which sectors have been liberalized and households' earning sources. Individuals working in the export sector, for instance, will enjoy gains, while those working in import competing sectors may face losses, with policy effects operating through resource reallocation and the displacement of workers (Winters \& Martuscelli, 2014; Federici \& Montalbano, 2010).

Liberalization policy can have an immediate impact in the form of access to more varieties of goods and services available to both producers and consumers. Its effect also operates through how price changes induced by liberalization affect different income groups (Deaton, 1989; Benjamin \& Deaton, 1993; Raihan, 2010). Public spending on welfare may fall, since government revenues generated in the form of tariffs are likely to be affected by liberalization (Ingco, 1997). 
The impact of liberalization can also operate through how relative wages are determined in a country. The standard Heckscher-Ohlin model predicts that trade liberalization is advantageous to factor-abundant countries, in this case, developing countries with abundant unskilled labor. Advocates of liberalization support this argument, pointing to the rising skill premium in the US. That said, this argument has been challenged with respect to developing countries (Topalova, 2007). Liberalization may induce capital deepening - which requires skills to complement capital - and support skilled labor instead, resulting in an increase in relative wages. In this sense, liberalization does not necessarily improve income distribution.

In the case of developing countries where product markets tend to be imperfect, protection may lead to rent sharing and liberalization may promote rent dissipation and increase relative wages (Robbins, 2003). In tandem with rising growth and wages due to liberalization, an increase in the returns to education can promote investment in education. In the long run, this would count as a positive impact of liberalization.

With global integration, faster economic growth and poverty reduction require an adjustment period. This can be costly, with poor households often bearing the burden (Banerjee \& Newman, 2004). Despite the benefits and losses to some in the short and long run, the advantages of liberalization - in terms of technology diffusion, efficiency of international trade and exchange, and the merits of living in an open society - are thought to outweigh its disadvantages. This warrants further research to identify the role of liberalization in determining the welfare of individuals in a society.

Pakistan initially followed an import substitution policy before moving toward liberalization. After becoming a member of WTO, the country was required to reduce its trade barriers and liberalized its trade in 2001 (Wacziarg \& Welch, 2008). This paper examines the relationship between trade liberalization and welfare for Pakistan over the years 1986 to 2015. Given the dearth of studies on the relationship between welfare and trade liberalization, it aims to contribute to the literature by examining the impact of trade liberalization on welfare in Pakistan using consumption as a measure of welfare.

The paper also analyzes the correlation between social indicators and trade liberalization to gauge whether the latter's benefits translate into consumption gains alone or if there are any improvements in education and health as well as declining poverty and inequality. There is no other evidence of this relationship for Pakistan. The study's findings suggest that the benefits of trade liberalization are more pronounced in the long run in 
terms of improved welfare in the shape of higher enrolment, reductions in poverty and lower inequality, while there is little evidence of these benefits in the short run.

Section 2 outlines Pakistan's trade policy. Sections 3 and 4 present the study's methodology and results. Section 5 concludes.

\section{Pakistan's Trade Policy}

Initially, Pakistan's trade policy focused on import substitution with the imposition of tariffs, quantitative restrictions, import licensing and nontariff barriers to protect domestic industry from foreign competition. In the 1960s, its trade policy emphasized export promotion through an export bonus scheme and by providing preferential access to foreign exchange. Import liberalization policies were also pursued, which included the renewal of import licenses and reduction in import controls. The economy experienced a large deficit in the balance of trade, which was financed by foreign loans. The export bonus scheme continued into the 1970s, accompanied by the elimination of restrictive licensing and currency devaluation. These policies did not increase exports relative to imports, thus leading to a current account deficit that was financed primarily through external sources.

To increase exports and imports, the government took several steps in the 1980s, including the removal of import quotas on noncapital imports and the liberalization of restricted imports by setting tariff rates for these imports and reducing tariff slabs. The economy continued to experience a current account deficit, albeit a smaller one than in the last decade. The reduction in imports, increase in remittances and foreign assistance received during the Afghan war led to an improvement in the balance of payments. During the 1990s, Pakistan's trade policy moved further toward trade liberalization. Nontariff barriers were removed, all items were allowed as imports, the maximum level of tariff was reduced, and export finance and credit guarantee schemes were launched. The current account deficit worsened the balance of payments, and this was exacerbated by the decline in remittances and foreign aid accompanied by economic sanctions.

Pakistan liberalized its economy in 2001 and continued to pursue a trade liberalization agenda. Export promotion measures included the provision of a freight subsidy of 25 percent for exports of new products. This policy continued till 2005 for leather products. Pakistan also signed different trade agreements, including a preferential trade agreement (PTA) with the ECO countries, the South Asian Free Trade Agreement with the SAARC 
countries and a PTA with China. Its exports benefited from the GSP Scheme under which Pakistani goods were given duty-free access to EU markets.

Subsequently, the country's trade policy focused on promoting exports through the development of clusters and the establishment of agricultural export processing zones and special export zones. Under this policy, services were considered a major industry with considerable export potential. The 25 percent freight subsidy policy continued and was extended to finished furniture goods. In 2005, as a member of WTO, Pakistan removed all quotas from imports. Second-hand goods were also added to the list of imports allowed. Once sanctions were lifted, foreign aid inflows rose. The country also experienced a large influx of remittances, which improved the balance of payments. The increase in oil prices, however, led to large import bills. Exports increased, primarily in rice, textiles, leather footwear, engineering goods and cement. Imports also rose, largely in textile machinery, agricultural machinery and chemicals.

The 2005/06 Rapid Export Growth Strategy aimed to improve market access for exports and target new markets. Pakistan initiated a free trade agreement (FTA) with Sri Lanka, a PTA with China and bilateral negotiations with Malaysia, Singapore, Indonesia, Turkey, Kazakhstan and other countries, as well as preferential access arrangements with SAARC and the ECO. Under the GSP scheme, all Pakistan's major exports could now enter the EU at concessional tariffs. Import liberalization was also part of this policy: more items were allowed into the country with standards prescribed. Exports increased by 14.14 percent over the previous year, but the increase in the import bill due to rising oil prices widened the trade gap.

In 2006, the Trade Development Authority of Pakistan (TDAP) was established to enhance trade. The 25 percent freight subsidy scheme was extended to goods exported to Africa and Eastern Europe. Customs duties on imported raw material and equipment - such as marble and marble machinery, horticulture and its machinery, raw material for footwear and rice boiling plants - were reduced. The increase in oil prices continued to generate high import bills and the economy experienced an increase in exports, primarily in textiles and in gems and jewelry.

Pakistan's trade policy focused on improving the competitiveness and productivity of exports through the provision of long-term financing. A social, environmental and security compliance board was proposed under the TDAP to ensure export quality standards. The country's import policy continued to emphasize liberalization, allowing industrial units to import 
machinery under specific regulations and standards as well as second-hand goods and machinery with stated age of use. As imports increased, the current account deficit continued for several reasons: the increase in oil prices, the wheat crisis and resulting wheat imports, the increase in palm oil prices, and the shortage of cotton, leading to cotton imports.

The trade policy of 2008/09 aimed to increase exports in several ways, including export diversification, trade promotion by the TDAP through exhibitions and trade fairs, the development of export clusters, and the establishment of the Federal Export Promotion Board and Trade Dispute Settlement Organization. The government also allowed inputs for exports to be imported at a zero rate of duty. An FTA with China was launched to establish industrial units in China-specific zones in Pakistan. Other key agreements included Pakistan's participation in SAFTA and the Regional Agreement on Trade in Services among the SAARC countries. However, the decline in economic activity in the US and EU led to a fall in Pakistan's exports, especially in textiles. Most recently, the country's trade policy has continued to focus on increasing export competitiveness and diversification with the provision of long-term loans. The policy also emphasizes increasing the number of FTAs with Pakistan's major trading partners. But, even in the presence of these policies, the trade deficit has continued to expand at an alarming rate, with rising imports and stagnant exports.

\section{Methodology}

This article examines the relationship between trade liberalization and welfare, using data from the World Development Indicators for the period 1986-2015. Welfare is measured by consumption expenditure, which is considered a better measure than income. ${ }^{1}$ The welfare model is illustrated below, where welfare measured by consumption is a function of income or output, trade volume and government expenditure:

\footnotetext{
${ }^{1}$ Various forms of consumption can be used to measure welfare, including the log of consumption, growth in consumption, consumption equivalent and the difference between expected and observed levels of consumption growth. The debate in the literature pertains to the relative merits of income and consumption as measures of welfare. Consumption offers several advantages at the individual as well as collective level and is considered a more direct measure of wellbeing than income. It is less likely to suffer from underreporting or reporting bias. Measurement problems with income are problematic when one is analyzing changes in the wellbeing of the poor since it may be correlated with government policies in the form of social safety nets. Thus, consumption is also appropriate in cases where people do not earn any form of income and represents a true measure of their welfare. On the other hand, consumption is most likely to be smoothed over a period whereas income may be more fluctuating. Various studies have justified the use of consumption as a measure of welfare, including Jones and Klenow (2010); Topalova (2007); Meyer and Sullivan (2003); Deaton (1989); Federici and Montalbano (2010); Raihan (2010); Pradhan (2009).
} 
$C=f(Y, T, G)$

where consumption is represented by $C$, real income by $Y$ (measured as real GDP), trade liberalization (exports and imports) by $T$ and government expenditure by $G$.

Consumption is measured by household final consumption expenditure, which is the market value of all goods and services (including durables) purchased by the household. Income is measured by GDP at the purchaser's price, which is the sum of gross value added by all resident producers in the economy plus any product taxes and minus any subsidies not included in the value of the products. Trade liberalization is measured as the sum of exports and imports of goods and services. ${ }^{2}$ Government expenditure is general government final consumption expenditure, which includes all government current expenditure on the purchase of goods and services, including employee compensation. All variables used are measured in constant 2010 US dollars and in log form. Figure 1 shows an upward trend in consumption and trade, both of which increased rapidly post-liberalization (post-2000). The empirical analysis will determine if the increase in welfare is attributable to trade.

Figure 1: Trade and final consumption expenditure trends, 1968 to 2012

Final consumption

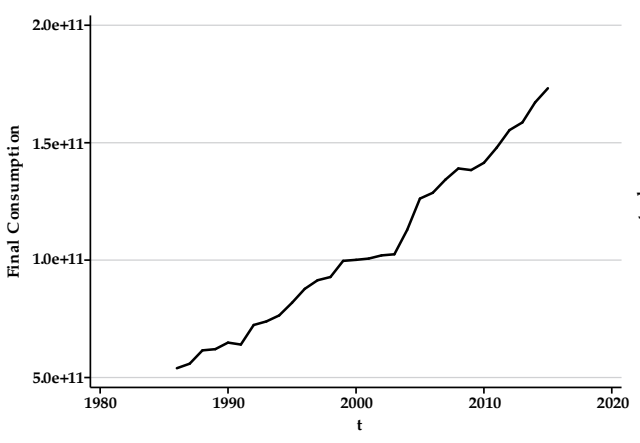

Trade

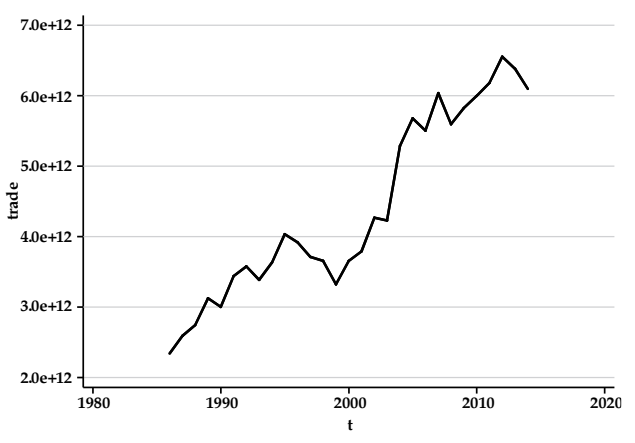

Table 1 gives the summary statistics for consumption and trade before (1986-2000) and after (2001-15) trade liberalization. We see that both

\footnotetext{
2 Various measures can be used to gauge openness or trade liberalization, including exports (or imports) as a percentage of GDP, the ratio of exports plus imports to GDP, a dummy variable for the year in which a country liberalized its trade, the index of trade liberalization and tariffs. We use the sum of exports and imports to measure trade liberalization rather than considering their ratio to GDP since the model already includes income as a separate independent variable. There is an extensive literature to support this choice of variable. See, for instance, Harrison (1996); Frankel and Romer (1996, 1999); Yanikkaya (2003); Burgoon (2001); Bekaert, Harvey and Lundblad (2005).
} 
average consumption and trade have risen over the years, as have their standard deviations from the mean.

Table 1: Summary statistics

\begin{tabular}{lll}
\hline Variable & \multicolumn{1}{c}{$\mathbf{1 9 8 6 - 2 0 0 0}$} & \multicolumn{1}{c}{$\mathbf{2 0 0 1 - 1 5}$} \\
\hline Final household consumption & & \\
$\quad$ Average & $75,900,000,000$ & $135,000,000,000$ \\
$\quad$ Standard deviation & $15,600,000,000$ & $23,300,000,000$ \\
Trade & & \\
$\quad$ Average & $3,230,000,000,000$ & $5,410,000,000,000$ \\
$\quad$ Standard deviation & $565,000,000,000$ & $963,000,000,000$ \\
\hline
\end{tabular}

Source: Author's calculations based on data from the World Development Indicators.

The model specified in equation (1) cannot be estimated using ordinary least squares since the variables at level may be nonstationary. We therefore employ a vector error correction model (VECM) ${ }^{3}$ to provide evidence of the long-run relationship between welfare and trade:

$\Delta C_{t}=\alpha_{0}+\sum_{i=1}^{k} \alpha_{1, i} \Delta X_{t-i}+\sum_{i=1}^{k} \alpha_{2, i} \Delta C_{t-i}+\sum_{i=1}^{k} \theta e c t_{t-i}+\varepsilon_{t}$

where $C$ is consumption, $X$ is a vector of all the independent variables specified above (T, G and $Y$ ), ect is the error correction term, $\alpha$ is the shortrun impact of the independent variables, $\theta$ is the parameter of the error correction term (ect) measuring the error correction mechanism that drives $X_{t}$ and $C_{t}$ back to their long-run equilibrium, and $i$ is the number of lags to be included in the VECM specification.

To obtain consistent estimates, we start by determining the presence of a unit root using the augmented Dickey-Fuller (ADF) test. The results in Table 2 show that all the variables are nonstationary at level, but stationary when first-differenced, at which point they are integrated of order one. We apply the Phillips-Perron test (see Table A1 in the Appendix) to check for stationarity and obtain similar results.

\footnotetext{
${ }^{3}$ The VECM allows for bidirectional causality between all the variables in the model and these variables are dealt with symmetrically in the estimations. We focus on the direction of the relationship running from liberalization to welfare and other social indicators, not the other way around. However, the literature on growth and liberalization does point out that openness measured by imports plus exports is likely to be endogenous. See, for example, Rodriguez and Rodrik (2001); Frankel and Romer (1999); Irwin and Terviö (2002); Winters, McCulloch and McKay (2002).
} 
Table 2: ADF test statistics

\begin{tabular}{lccc}
\hline Variable & Level t-statistic & $\begin{array}{c}\text { First-difference } \\
\text { test statistic }\end{array}$ & $\begin{array}{c}\text { Order of } \\
\text { integration }\end{array}$ \\
\hline In consumption $(\mathrm{C})$ & -0.831 & $-6.001^{* * *}$ & $\mathrm{I}(1)$ \\
Ln GDP $(\mathrm{Y})$ & -1.408 & $-3.277^{* *}$ & $\mathrm{I}(1)$ \\
Ln trade $(\mathrm{T})$ & -1.635 & $-5.739^{* * *}$ & $\mathrm{I}(1)$ \\
Ln government & -0.027 & $-7.097^{* * *}$ & $\mathrm{I}(1)$ \\
expenditure (G) & & & \\
\hline
\end{tabular}

Note: If test statistic $>$ critical value, we reject $\mathrm{H}_{\mathrm{o}}$ of nonstationarity.

Source: Author's calculations.

Since all the variables are integrated of the same order, there may also be a linear combination between the variables that is stationary. Thus, we need to determine whether the variables are cointegrated. This is done using the Johansen and Juselius multivariate trace and maximal eigenvalue cointegration test. We check for cointegration and determine the rank of the cointegrating vectors, the results of which are presented in Table 3.

Table 3: Cointegration test results for welfare model (JohansenJuselius maximum likelihood method)

\begin{tabular}{cccc}
\hline \multicolumn{3}{c}{$C_{t}=\alpha_{o}+\alpha_{1} T_{t}+\alpha_{2} Y_{t}+\alpha_{3} G_{t}+\mu_{t}$} & \\
Null hypothesis & $\begin{array}{c}\text { Alternative } \\
\text { hypothesis }\end{array}$ & $\begin{array}{c}\text { Cointegration test } \\
\text { statistic }\end{array}$ & 1\% critical value \\
\hline$r=0$ & $r>0$ & 95.0981 & 54.64 \\
$r \leq 1$ & $r>1$ & 45.4542 & 34.55 \\
$r \leq 2$ & $r>2$ & $14.0563^{*}$ & 18.17 \\
\hline
\end{tabular}

Source: Author's calculations.

The trace statistics obtained are greater than the critical values for $r$ $=2$. This implies that the null hypothesis of no cointegration is rejected for the trace tests. The trace statistics test the null hypothesis that the number of cointegrating relationships is $r$ against $k$ cointegrating relationships, where $k$ is the number of endogenous variables. The results suggest that there are at least two cointegrating vectors. Although the series at level is nonstationary, it is integrated of the same order, indicating that there exists a linear combination between the series that is stationary. We conclude that the variables are cointegrated and a VECM can be estimated.

The lags for the VECM are determined using several pre-estimation diagnostic tests: the Akaike information criterion (AIC), the Hannan- 
Quinn criterion (HQC) and the Schwarz Bayesian criterion (SBIC). The results for the lag order selection are given in Table 4. According to the AIC, the lag length is 4, while the HQC and SBC yield a lag length of $1 .{ }^{4}$ We select the lag length using the AIC.

Table 4: Lag order selection criteria for welfare model

\begin{tabular}{cccc}
\hline Lags & AIC & HQC & SBC \\
\hline 0 & -7.89458 & -7.83884 & -7.70103 \\
1 & -14.46200 & $-14.18330^{*}$ & $-13.49420^{*}$ \\
2 & -14.46220 & -13.96060 & -12.72020 \\
3 & -13.96880 & -13.24420 & -11.45260 \\
4 & $-14.68590^{*}$ & -13.73840 & -11.39550 \\
\hline
\end{tabular}

Source: Author's calculations.

\section{Results}

This section presents the results for the relationship between welfare and trade liberalization and between social indicators and trade liberalization.

\subsection{Relationship Between Welfare and Trade Liberalization}

The results for the VECM using equation (2) are presented in Table 5 , which gives the long-run and short-run estimates of welfare in terms of consumption with respect to trade, GDP and government expenditure.

\footnotetext{
${ }^{4}$ The results are verified by changing the lag length.
} 
Table 5: Welfare VECM short-run and long-run estimates

\begin{tabular}{|c|c|c|c|}
\hline Variable & Short run & $\begin{array}{c}\text { Long run } \\
\text { (1st cointegrating } \\
\text { equation) }\end{array}$ & $\begin{array}{c}\text { Long run } \\
\text { (2nd cointegrating } \\
\text { equation) }\end{array}$ \\
\hline$\Delta C_{t-1}$ & $\begin{array}{l}-0.156 \\
(0.598)\end{array}$ & 1 & $-5.33 \mathrm{e}-15$ \\
\hline$\Delta C_{t-2}$ & $\begin{array}{l}0.212 \\
(0.534)\end{array}$ & & \\
\hline$\Delta C_{t-3}$ & $\begin{array}{l}0.090 \\
(0.473)\end{array}$ & & \\
\hline$\Delta Y_{t-1}$ & $\begin{array}{l}0.499 \\
(0.225)\end{array}$ & $\begin{array}{l}-0.773^{* * *} \\
(0.293)\end{array}$ & \\
\hline$\Delta Y_{t-2}$ & $\begin{array}{l}-0.743 \\
(0.369)\end{array}$ & & $\begin{array}{l}24.639^{* * * *} \\
(8.487)\end{array}$ \\
\hline$\Delta Y_{t-3}$ & $\begin{array}{l}-1.350^{*} \\
(0.664)\end{array}$ & & \\
\hline$\Delta T_{t-1}$ & $\begin{array}{l}0.038 \\
(0.209)\end{array}$ & $\begin{array}{l}0.0749 \\
(0.324)\end{array}$ & \\
\hline$\Delta T_{t-2}$ & $\begin{array}{l}0.297 \\
(0.196)\end{array}$ & & $\begin{array}{l}21.011^{* *} \\
(9.390)\end{array}$ \\
\hline$\Delta T_{t-3}$ & $\begin{array}{l}0.270^{*} \\
(0.159)\end{array}$ & & \\
\hline$\Delta G_{t-1}$ & $\begin{array}{l}-0.0182 \\
(0.145)\end{array}$ & $1.73 \mathrm{e}-18$ & 1 \\
\hline$\Delta G_{t-2}$ & $\begin{array}{l}-0.006 \\
(0.154)\end{array}$ & & \\
\hline$\Delta G_{t-3}$ & $\begin{array}{l}0.063 \\
(0.105)\end{array}$ & & \\
\hline Constant & $\begin{array}{l}0.064^{* *} \\
(0.028)\end{array}$ & & \\
\hline Error correction term 1 & $\begin{array}{l}-0.200 \\
(0.342)\end{array}$ & & \\
\hline Error correction term 2 & $\begin{array}{l}0.003 \\
(0.001)\end{array}$ & & \\
\hline R-squared & 0.834 & & \\
\hline $\mathrm{N}$ & 26 & & \\
\hline
\end{tabular}

Note: Dependent variable $=\mathrm{C}$. Independent variables $=\mathrm{Y}, \mathrm{T}$ and $\mathrm{G}$. The equation was estimated with four lags of the independent variables and two cointegrating ranks for 19862015. All variables are in $\log$ form. Standard errors given in parentheses. ${ }^{* *}=1$ percent significance level, ${ }^{* *}=5$ percent significance level and ${ }^{*}=10$ percent significance level.

Source: Author's calculations. 
The short-run measure for trade shows that trade liberalization in the previous two periods has no significant relationship with welfare. However, it does have a significant relationship with welfare after a three period lag. This indicates that trade liberalization policies do not have an immediate impact, but that their effect emerges over time. Thus, welfare or consumption does not respond to changes in trade in the short run. In the long run, there is a positive and significant relationship between trade and welfare. The coefficient estimate indicates that an increase in trade is associated with higher levels of welfare. This is as expected: trade liberalization enhances welfare in the long run once the positive benefits of opening up the economy to international markets emerge. The results suggest that, in the short run, countries may experience a decrease in consumption, perhaps due to increasing vulnerability as the economy opens up. In the long run, however, the benefits of openness - such as access to cheaper imports or greater availability of goods and services become apparent.

The results for income indicate that it plays an important role in determining welfare. The positive relationship between income and welfare also holds in the long run, which indicates that an increase in GDP or income leads to an increase in household welfare or consumption. The third determinant of welfare or consumption is government expenditure. The results show that there is no relationship between the two variables either in the short run or long run. This implies that government policies of higher expenditure or providing direct assistance have an insignificant impact on welfare, which may point to the nature of government expenditures in Pakistan rather than their efficacy in general.

The results of this estimation reveal that both trade liberalization and GDP enhance welfare in Pakistan and that policy choices play an important role in determining welfare. However, this welfare-enhancing impact is not necessarily immediate, but emerges in the long term. The cointegrating vector captures the long-run relationship between the variables and (in matrix form) is written as

$$
\hat{\prod}=\left(\begin{array}{c}
1,-0.773,0.074,1.73 \mathrm{e}-18 \\
-5.33 \mathrm{e}-15,24.639,21.011,1
\end{array}\right)
$$

We test for autocorrelation among the residuals. The results given in Table 6 indicate that we cannot reject the null hypothesis of no autocorrelation for the two lags. Next, we test for the normality of the error terms using the Jarque-Bera test. The results indicate that we cannot reject 
the null hypothesis of normally distributed errors. Thus, the errors are not skewed and there is no kurtosis.

Table 6: Results of VECM stability tests for welfare model

\begin{tabular}{lcc}
\hline Tests for stability check & Chi-sq. value & P-value of chi-sq. \\
\hline Lagrange multiplier test* $(\operatorname{lag} 1)$ & 8.954 & 0.91500 \\
Lagrange multiplier test* $(\operatorname{lag} 2)$ & 9.170 & 0.90600 \\
Jarque-Bera test** & 4.464 & 0.81302 \\
Skewness & 2.387 & 0.66494 \\
Kurtosis & 2.077 & 0.72162 \\
\hline
\end{tabular}

Note: ${ }^{*}=\mathrm{H}_{\mathrm{o}}$ (no autocorrelation at lag order). ${ }^{* *}=\mathrm{H}_{\mathrm{o}}$ (error terms are normally distributed).

Source: Author's calculations.

\subsection{Relationship Between Social Indicators and Trade Liberalization}

In addition to analyzing welfare, we examine whether there is any correlation between trade liberalization and social indicators capturing poverty, education, health and inequality. Trade liberalization is expected to increase welfare and similarly to improve individuals' standard of living. The study's rationale is that, since trade liberalization is expected to improve exports and imports, this should be accompanied by increased employment opportunities, reduced poverty, increased school enrollment and better health outcomes. We do not focus on import and export performance since the literature already indicates their importance. To examine the relationship between trade liberalization and social indicators, we use data from the World Development Indicators. The welfare variables in equation (1) are replaced with social indicators, while the independent variables remain the same. The study aims to establish correlation rather than causation.

We use life expectancy to gauge health outcomes, measured by the number of years a newborn infant would live if prevailing patterns of mortality at the time of its birth were to remain constant throughout its life. Inequality is measured using World Bank estimates of the GINI index, defined as the extent to which the distribution of income among individuals or households within an economy deviates from a perfectly equal distribution. Education outcomes are measured by the total number of children enrolled at primary level in public and private schools. Finally, the depth and incidence of poverty is measured by the poverty gap at US\$1.90 a day, defined as the mean shortfall in income or 
consumption relative to the poverty line and expressed as a percentage of the poverty line (where the nonpoor have a zero shortfall). All the variables are used in log form.

To estimate the model, we use the ADF test to check for stationarity. The results in Table 7 show that life expectancy is integrated of order 0 , while primary enrolment, the poverty gap and the GINI index are integrated of order 1 . We choose the appropriate model based on the ADF test and cointegration results.

Table 7: ADF test statistics

\begin{tabular}{lccc}
\hline Variable & Level t-statistic & $\begin{array}{c}\text { First-difference } \\
\text { test statistic }\end{array}$ & $\begin{array}{c}\text { Order of } \\
\text { integration }\end{array}$ \\
\hline Ln life expectancy (L) & $-14.970^{* * *}$ & - & $\mathrm{I}(0)$ \\
Ln primary enrolment (E) & -0.254 & $-6.697^{* * *}$ & $\mathrm{I}(1)$ \\
Ln poverty gap (P) & -0.925 & $-4.905^{* * *}$ & $\mathrm{I}(1)$ \\
Ln GINI index (GINI) & -2.591 & $-4.323^{* * *}$ & $\mathrm{I}(1)$ \\
\hline
\end{tabular}

Note: If test statistic > critical value, we reject Ho of nonstationarity.

Source: Author's calculations.

Since life expectancy is integrated of order 0 , while the independent variables are integrated of order 1 (as shown in Table 2), we select the autoregressive distributed lag model (ARDL) and select a lag length of $3 .{ }^{5}$ Given that primary enrolment, the poverty gap and the GINI index are integrated of order 1, we also test for cointegration, the results of which are presented in Table 8 . The primary enrolment and poverty gap models are cointegrated of rank 1 and, therefore, we estimate a VECM in both cases. Since the GINI index is not cointegrated, we estimate a vector autoregressive model (VAR) in this case.

Table 8: Cointegration test results (Johansen-Juselius maximum likelihood method)

\begin{tabular}{cccccc}
\hline & & & \multicolumn{2}{c}{ Cointegration test statistic for } \\
\cline { 4 - 6 } $\begin{array}{c}\text { Null } \\
\text { hypothesis }\end{array}$ & $\begin{array}{c}\text { Alternative } \\
\text { hypothesis }\end{array}$ & $\begin{array}{c}\mathbf{5 \%} \text { critical } \\
\text { value }\end{array}$ & $\begin{array}{c}\text { Primary } \\
\text { enrolment }\end{array}$ & Poverty gap & GINI index \\
\hline$r=0$ & $r>0$ & 29.68 & 40.55 & 44.31 & $22.27^{*}$ \\
$r \leq 1$ & $r>1$ & 15.41 & $14.83^{*}$ & $15.07^{*}$ & 7.36 \\
\hline
\end{tabular}

Source: Author's calculations.

\footnotetext{
${ }^{5}$ Selected based on visual inspection.
} 
Table 9 gives the lag order selection criteria used, according to which we select 4 as the lag length for primary enrolment, the poverty gap and the GINI index.

Table 9: Lag order selection criteria

\begin{tabular}{llllllllll}
\hline & \multicolumn{3}{c}{ Primary enrolment } & \multicolumn{3}{c}{ Poverty gap } & \multicolumn{3}{c}{ GINI index } \\
\cline { 2 - 9 } Lags & AIC & HQC & SBC & AIC & HQC & SBC & AIC & HQC & SBC \\
\hline 0 & -3.76 & -3.70 & -3.59 & -2.58 & -2.53 & -2.38 & -7.08 & -7.04 & -6.88 \\
1 & -11.84 & -11.53 & $-10.99^{*}$ & -8.20 & -7.96 & -7.21 & -12.13 & -11.93 & -11.13 \\
2 & -11.76 & -11.21 & -10.24 & -8.40 & -7.98 & -6.61 & -12.67 & -12.32 & -10.88 \\
3 & -11.57 & -10.78 & -9.38 & -8.62 & -8.01 & -6.04 & -14.45 & -13.94 & -11.86 \\
4 & $-12.30^{*}$ & $-11.2^{*}$ & -9.43 & $-12.94^{*}$ & $-12.14^{*}$ & $-9.56^{*}$ & $-51.64^{*}$ & $-50.98^{*}$ & $-48.25^{*}$ \\
\hline
\end{tabular}

Source: Author's calculations.

Table 10 gives the estimation results for the four social indicators, with life expectancy, primary enrolment, the poverty gap and the GINI index as the dependent variables. The lagged values of the dependent variables (represented by $\mathrm{Z}$ ), income, government spending and trade liberalization and their lags are the independent variables. ${ }^{6}$

${ }^{6}$ All the independent variables are the same as used in Table 5. 
Table 10: Short-run and long-run estimates of social indicators

\begin{tabular}{|c|c|c|c|c|c|c|}
\hline \multirow[b]{3}{*}{ Variable } & \multirow{3}{*}{$\begin{array}{c}\text { ARDL } \\
\begin{array}{c}\text { Life } \\
\text { expectancy }\end{array}\end{array}$} & \multicolumn{4}{|c|}{ VECM } & \multirow{3}{*}{$\begin{array}{c}\text { VAR } \\
\text { GINI } \\
\text { index }\end{array}$} \\
\hline & & \multicolumn{2}{|c|}{ Primary enrolment } & \multicolumn{2}{|c|}{ Poverty gap } & \\
\hline & & Short run & Long run & Short run & Long run & \\
\hline & (1) & $(2)$ & (3) & $(4)$ & (5) & (6) \\
\hline$Z_{t-1}$ & $\begin{array}{l}2.240^{* * *} \\
(0.144)\end{array}$ & $\begin{array}{l}-0.234 \\
(0.213)\end{array}$ & & $\begin{array}{l}0.527 \\
(0.435)\end{array}$ & & $\begin{array}{l}0.364^{*} \\
(0.216)\end{array}$ \\
\hline$Z_{t-2}$ & $\begin{array}{l}-1.646^{* * * *} \\
(0.253)\end{array}$ & $\begin{array}{l}-0.190 \\
(0.208)\end{array}$ & & $\begin{array}{l}0.504 \\
(0.538)\end{array}$ & & $\begin{array}{l}-0.141 \\
(0.215)\end{array}$ \\
\hline$Z_{t-3}$ & $\begin{array}{l}0.394^{* * *} \\
(0.118)\end{array}$ & $\begin{array}{l}-0.359^{*} \\
(0.209)\end{array}$ & & $\begin{array}{l}0.343 \\
(0.507)\end{array}$ & & $\begin{array}{l}-0.344^{* *} \\
(0.162)\end{array}$ \\
\hline$Z_{t-4}$ & & & & & & $\begin{array}{l}-0.433^{* * *} \\
(0.167)\end{array}$ \\
\hline$Y_{t-1}$ & $\begin{array}{l}-0.001 \\
(0.0009)\end{array}$ & $\begin{array}{l}0.974 \\
(0.834)\end{array}$ & $\begin{array}{l}-4.828^{* * *} \\
(0.399)\end{array}$ & $\begin{array}{l}-2.646 \\
(8.847)\end{array}$ & $\begin{array}{l}4.971^{* * *} \\
(0.221)\end{array}$ & $\begin{array}{l}-1.540^{* * *} \\
(0.375)\end{array}$ \\
\hline$Y_{t-2}$ & $\begin{array}{l}0.003^{* *} \\
(0.001)\end{array}$ & $\begin{array}{l}-0.930 \\
(0.942)\end{array}$ & & $\begin{array}{l}4.498 \\
(10.03)\end{array}$ & & $\begin{array}{l}2.040^{* * * *} \\
(0.419)\end{array}$ \\
\hline$Y_{t-3}$ & $\begin{array}{l}-0.002 \\
(0.001)\end{array}$ & $\begin{array}{l}-1.621^{*} \\
(0.906)\end{array}$ & & $\begin{array}{l}10.51 \\
(9.746)\end{array}$ & & $\begin{array}{l}0.0635 \\
(0.482)\end{array}$ \\
\hline$Y_{t-4}$ & & & & & & $\begin{array}{l}-0.401 \\
(0.366)\end{array}$ \\
\hline$G_{t-1}$ & $\begin{array}{l}0.0001 \\
(0.0003)\end{array}$ & $\begin{array}{l}0.577^{* *} \\
(0.250)\end{array}$ & $\begin{array}{l}-0.848^{* * *} \\
(0.272)\end{array}$ & $\begin{array}{l}-2.613 \\
(1.878)\end{array}$ & $\begin{array}{l}2.187^{* * *} \\
(0.159)\end{array}$ & $\begin{array}{l}-0.284^{* * * *} \\
(0.077)\end{array}$ \\
\hline$G_{t-2}$ & $\begin{array}{l}-0.00004 \\
(0.0003)\end{array}$ & $\begin{array}{l}0.103 \\
(0.220)\end{array}$ & & $\begin{array}{l}-0.862 \\
(2.145)\end{array}$ & & $\begin{array}{l}0.101 \\
(0.099)\end{array}$ \\
\hline$G_{t-3}$ & $\begin{array}{l}-0.0003 \\
(0.0002)\end{array}$ & $\begin{array}{l}0.298^{*} \\
(0.176)\end{array}$ & & $\begin{array}{l}-1.098 \\
(1.250)\end{array}$ & & $\begin{array}{l}0.117 \\
(0.091)\end{array}$ \\
\hline$G_{t-4}$ & & & & & & $\begin{array}{l}0.129^{* *} \\
(0.051)\end{array}$ \\
\hline$T_{t-1}$ & $\begin{array}{l}0.0004 \\
(0.0002)\end{array}$ & $\begin{array}{l}-0.359 \\
(0.279)\end{array}$ & $\begin{array}{l}4.547^{* * *} \\
(0.477)\end{array}$ & $\begin{array}{l}-1.493 \\
(2.015)\end{array}$ & $\begin{array}{l}-5.833^{* * *} \\
(0.3265)\end{array}$ & $\begin{array}{l}0.108 \\
(0.103)\end{array}$ \\
\hline$T_{t-2}$ & $\begin{array}{l}-0.0003 \\
(0.0002\end{array}$ & $\begin{array}{l}-0.339 \\
(0.234)\end{array}$ & & $\begin{array}{l}2.236 \\
(3.107)\end{array}$ & & $\begin{array}{l}0.213^{* *} \\
(0.096)\end{array}$ \\
\hline$T_{t-3}$ & $\begin{array}{l}0.0001 \\
(0.0002)\end{array}$ & $\begin{array}{l}0.135 \\
(0.195)\end{array}$ & & $\begin{array}{l}-0.776 \\
(3.282)\end{array}$ & & $\begin{array}{l}-0.151 \\
(0.128)\end{array}$ \\
\hline$T_{t-4}$ & & & & & & $\begin{array}{l}-0.483^{* * *} \\
(0.171)\end{array}$ \\
\hline Constant & $\begin{array}{l}0.0238 \\
(0.0155)\end{array}$ & $\begin{array}{l}0.0141 \\
(0.0517)\end{array}$ & & $\begin{array}{l}-0.0223 \\
(0.621)\end{array}$ & & $\begin{array}{l}8.885^{* * *} \\
(2.110)\end{array}$ \\
\hline ECT & & $\begin{array}{l}0.155^{*} \\
(0.0884)\end{array}$ & & $\begin{array}{l}-0.677 \\
(0.424)\end{array}$ & & \\
\hline R-squared & 0.968 & 0.4116 & - & 0.5834 & - & 0.9167 \\
\hline Sample & 1967-2015 & 1971-2014 & 1971-2014 & 1987-2012 & 1987-2012 & 1987-2010 \\
\hline
\end{tabular}

Note: Dependent variables = life expectancy, primary enrolment, poverty gap and GINI index. Independent variables = lagged dependent variables, income, trade, government expenditure and lagged independent variables. All variables are used in log form. The ARDL model is estimated with three lags, the VECM in differenced form with rank 1 and four lags, and the VAR model with 4 lags. Sample size varies across estimations due to data availability. Standard errors given in parentheses. ${ }^{* *}=1$ percent significance level, ${ }^{* *}$ $=5$ percent significance level and ${ }^{*}=10$ percent significance level.

Source: Author's calculations. 
Column (1) gives the results for the life expectancy variable, estimated using an ARDL model with three lags of each variable. The results show that trade liberalization has no significant correlation with life expectancy. Columns (2) and (3) give the short-run and long-run estimates of the VECM using primary enrollment as a dependent variable. The results show that trade liberalization does not have a significant correlation with primary enrollment in the short run, but has a positive and significant correlation in the long run. This is consistent with our earlier finding that it takes time for trade liberalization policy to affect welfare. We can also see that government spending has a positive and significant correlation with enrollment in the short run, but this correlation becomes negative in the long run. This has implications for policymaking with respect to education spending.

Columns 4 and 5 give the short-run and long-run results of the VECM using the poverty gap as the dependent variable. The results are similar to those for primary enrollment: trade liberalization is associated with a decline in poverty in the long run, but there is no significant correlation in the short run. Column 6 gives the results for the GINI index, estimated using a VAR model with a lag length of 4 . The two year lagged trade variable has a positive correlation with inequality, but after four years, trade has a negative correlation with inequality. What we conclude from this is that, post-trade liberalization, inequality initially rises but after few years will fall. An interesting finding is that government spending may decrease inequality in the short run, but tends to increase inequality over time.

\subsection{Discussion}

The study's results show that trade liberalization policies do not have an immediate impact on welfare, education, poverty and inequality. Instead, their effects on welfare and other social indicators tend to emerge over time. The empirical literature supports the argument that liberalization does not have an adverse impact on welfare, although it is not the only channel through which poverty can be reduced. While trade liberalization implies significant distributional changes and may reduce welfare in the short run, it is likely to enhance welfare in the long run (Winters, McCulloch \& McKay, 2004). The consensus is that liberalization boosts incomes and reduces poverty (Winters \& Martuscelli, 2014).

Our empirical results differ somewhat with the literature for developed and developing countries. Ingco (1997), for instance, finds that liberalization leads to an increase in welfare; these welfare gains are higher for poorer households than for richer households in developed countries. 
Federici and Montalbano (2010) find consistent evidence for the same argument in the case of developing countries. Looking at Bangladesh, Raihan (2010) shows that trade liberalization has a negative impact on welfare and GDP in the short run, while consumption tends to grow for all income groups. The benefits of trade liberalization are most pronounced for the poorest households. Our results, on the other hand, point to an increase in inequality in the short run, meaning the richer households benefit more from trade liberalization than poorer households.

Liberalization has also helped reduce wage inequality in India, for example (Kumar \& Mishra, 2008). While there is consensus on the shortrun loss that follows trade liberalization, this loss is smaller than the longrun gains that can be expected (Mishra \& Topalova, 2007). Some studies, however, disagree. In Indian districts with a concentration of industries more exposed to liberalization, the incidence and depth of poverty fell by less than expected as a result of trade liberalization - a setback of about 15 percent of India's progress toward poverty reduction during the 1990s. Moreover, inequality remained unaffected for the sample of Indian states in both urban and rural areas (Topalova, 2007).

\section{Conclusion}

Policy choices play an important role in determining growth. To this end, most developing countries have initiated liberalization policies to reap the benefits of globalization. Indeed, a country's trade policy often reflects its overall policy choices with respect to growth and welfare.

This study examines the relationship between trade liberalization and welfare and other social indicators for Pakistan over the period 19862015. Despite the substantial literature examining the impact of economic growth and trade liberalization, few studies have looked at the relationship between welfare and trade liberalization. This study contributes to the literature by examining this relationship, using consumption to gauge welfare. It also measures the correlation between social indicators and trade liberalization to determine if the latter's benefits translate into consumption gains alone or if they are associated with improvements in education and health, and declining poverty and inequality.

The empirical results reveal that trade liberalization policy may have no effect (or in the case of income inequality, a negative effect) on welfare in the short run. Instead, its benefits emerge over time in terms of poverty reduction, declining inequality and an increase in enrollment. The benefits of trade liberalization may only be experienced after a number of years. 


\section{References}

Banerjee, A., \& Newman, A. (2004). Inequality, growth and trade policy. Unpublished manuscript, Massachusetts Institute of Technology, Department of Economics, and University College London, Department of Economics.

Bekaert, G., Harvey, C. R., \& Lundblad, C. (2005). Does financial liberalization spur growth? Journal of Financial Economics, 77(1), 3-55.

Benjamin, D., \& Deaton, A. (1993). Household welfare and the pricing of cocoa and coffee in Cote d'Ivoire: Lessons from the Living Standards Surveys. World Bank Economic Review, 7(3), 293-318.

Burgoon, B. (2001). Globalization and welfare compensation: Disentangling the ties that bind. International Organization, 55(3), 509-551.

Chatterji, M., Mohan, S., \& Dastidar, S. G. (2014). Relationship between trade openness and economic growth of India: A time series analysis. Journal of Academic Research in Economics, 6(1), 45-69.

Deaton, A. (1989). Rice prices and income distribution in Thailand: A non-parametric analysis. Economic Journal, 99(395), 1-37.

Din, M., Ghani, E., \& Siddique, O. (2003). Openness and economic growth in Pakistan. Pakistan Development Review, 42(4), 795-807.

Federici, A., \& Montalbano, P. (2010). Does trade openness make countries vulnerable? (Working Paper No. 3/10). Rome: Sapenzia University.

Frankel, J. A., \& Romer, D. (1996). Trade and growth: An empirical investigation (Working Paper No. 5476). Cambridge, MA: National Bureau of Economic Research.

Frankel, J. A., \& Romer, D. (1999). Does trade cause growth? American Economic Review, 89(3), 379-399.

Gries, T., \& Redlin, M. (2012, March). Trade openness and economic growth: A panel causality analysis. Paper presented at the RCIE, KIET and APEA International Conference on the Global Economy, Seattle, WA.

Harrison, A. (1996). Openness and growth: A time-series, cross-country analysis for developing countries. Journal of Development Economics, 48(2), 419-447. 
Ingco, M. D. (1997). Has agricultural trade liberalization improved welfare in the least-developed countries? Yes (Policy Research Working Paper No. 1748). Washington, DC: World Bank.

Irwin, D. A., \& Terviö, M. (2002). Does trade raise income? Evidence from the twentieth century. Journal of International Economics, 58(1), 1-18.

Jones, C. I., \& Klenow, P. J. (2010). Beyond GDP? Welfare across countries and time (Working Paper No. 16352). Cambridge, MA: National Bureau of Economic Research.

Kumar, U., \& Mishra, P. (2008). Trade liberalization and wage inequality: Evidence from India. Review of Development Economics, 12(2), 291-311.

Meyer, B. D., \& Sullivan, J. X. (2003). Measuring the wellbeing of the poor using income and consumption (Working Paper No. 9760). Cambridge, MA: National Bureau of Economic Research.

Mishra, P., \& Topalova, P. (2007). How does globalization affect developing countries? IMF Research Bulletin, 8(3), 1-5.

Pradhan, M. (2009). Welfare analysis with a proxy consumption measure: Evidence from a repeated experiment in Indonesia. Fiscal Studies, 30(3-4), 391-417.

Raihan, S. (2010). Welfare and poverty impacts of trade liberalization: A dynamic CGE microsimulation analysis. International Journal of Microsimulation, 3(1), 123-126.

Robbins, D. J. (2003). The impact of trade liberalization upon inequality in developing countries: A review of theory and evidence (Working Paper No. 13). Geneva: ILO, International Policy Group.

Rodriguez, F., \& Rodrik, D. (2001). Trade policy and economic growth: A skeptic's guide to the cross-national evidence. NBER Macroeconomics Annual, 15, 261-338.

Sachs, J. D., \& Warner, A. (1995). Economic reform and the process of global integration. Brookings Papers on Economic Activity, 26(1), 1-118.

Siddiqui, A. H., \& Iqbal, J. (2005). Impact of trade openness on output growth for Pakistan: An empirical investigation. Market Forces, 1(1), 3-10. 
Topalova, P. (2007). Trade liberalization, poverty and inequality: Evidence from Indian districts. In A. Harrison (ed.), Globalization and poverty (pp. 291-336). Chicago: University of Chicago Press.

Wacziarg, R., \& Welch, K. H. (2008). Trade liberalization and growth: New evidence. World Bank Economic Review, 22(2), 187-231.

Winters, L. A., \& Martuscelli, A. (2014). Trade liberalization and poverty: What have we learned in a decade? Annual Review of Resource Economics, 6(1), 493-512.

Winters, L. A., McCulloch, N., \& McKay, A. (2002). Trade liberalization and poverty: The empirical evidence (CREDIT Research Paper No. 02/22). Nottingham: University of Nottingham.

Winters, L. A., McCulloch, N., \& McKay, A. (2004). Trade liberalization and poverty: The evidence so far. Journal of Economic Literature, 42(1), 72-115.

Yanikkaya, H. (2003). Trade openness and economic growth: A crosscountry empirical investigation. Journal of Development Economics, 72(1), 57-89.

Yasmin, B., Jehan, Z., \& Chaudhary, M. A. (2006). Trade liberalization and economic development: Evidence from Pakistan. Lahore Journal of Economics, 11(1), 19-34. 


\section{Appendix}

Table A1: Phillips-Perron test statistics for welfare model

\begin{tabular}{lccc}
\hline Variable & Level t-statistic & $\begin{array}{c}\text { First-difference } \\
\text { test statistic }\end{array}$ & $\begin{array}{c}\text { Order of } \\
\text { integration }\end{array}$ \\
\hline Consumption $(\mathrm{C})$ & 3.137 & $-4.089^{* * *}$ & $\mathrm{I}(1)$ \\
GDP $(\mathrm{Y})$ & 3.716 & $-2.641^{*}$ & $\mathrm{I}(1)$ \\
Trade $(\mathrm{T})$ & -0.658 & $-6.798^{* * *}$ & $\mathrm{I}(1)$ \\
Government/GDP $(\mathrm{G})$ & -1.785 & $-5.635^{* * *}$ & $\mathrm{I}(1)$ \\
\hline
\end{tabular}

Note: $\mathrm{Ho}=$ nonstationarity. If test statistic $>$ critical value, we reject Ho.

Figure A1: Ln of final consumption expenditure, 1968 to 2012

Before stationary

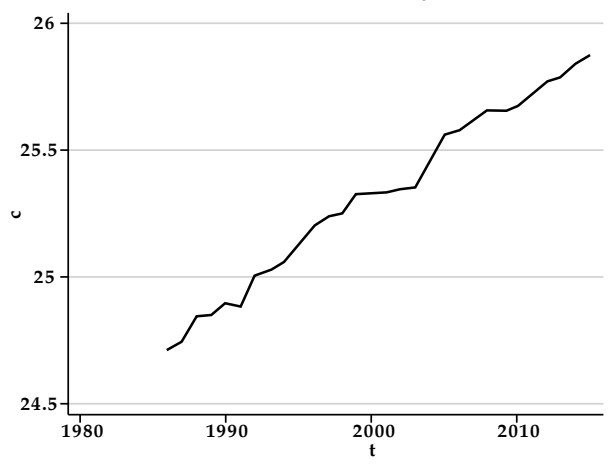

After stationary

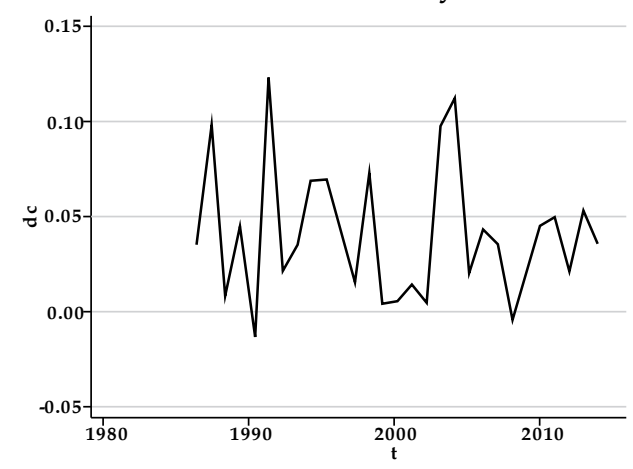

Source: Author's illustration.

Figure A2: Ln of government expenditure, 1968 to 2012

Before stationary

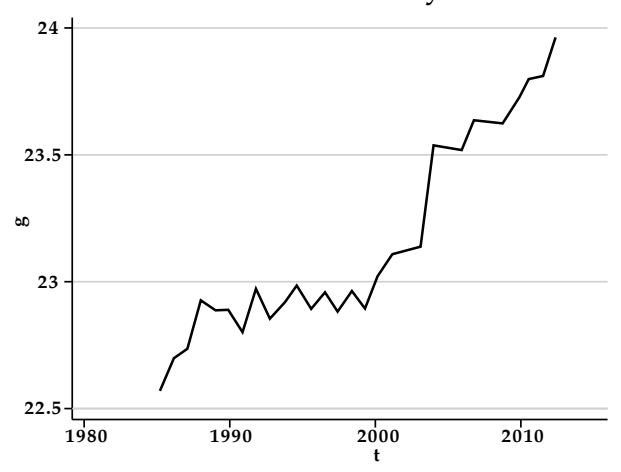

After stationary

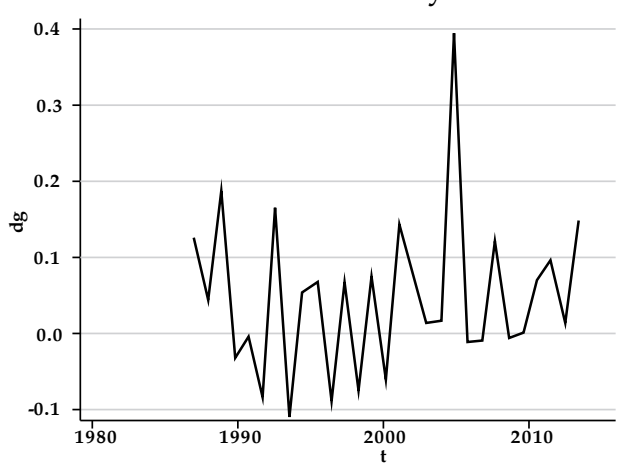

Source: Author's illustration. 


\section{Figure A3: Ln of trade, 1968 to 2012}

Before stationary

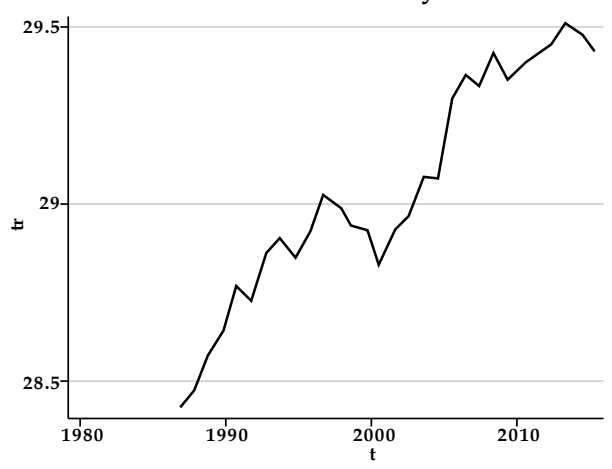

After stationary

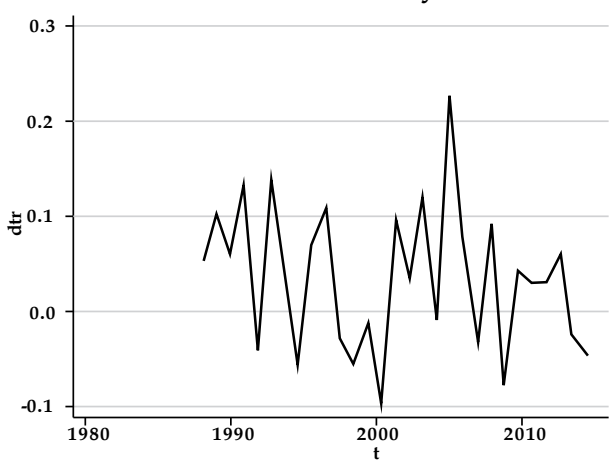

Source: Author's illustration.

Figure A4: Ln of income, 1968 to 2012

Before stationary

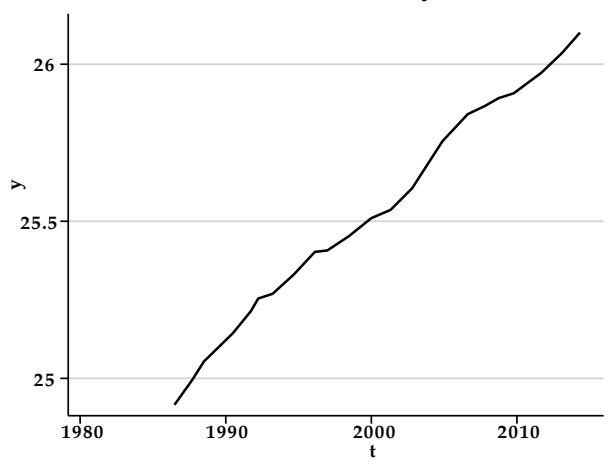

After stationary

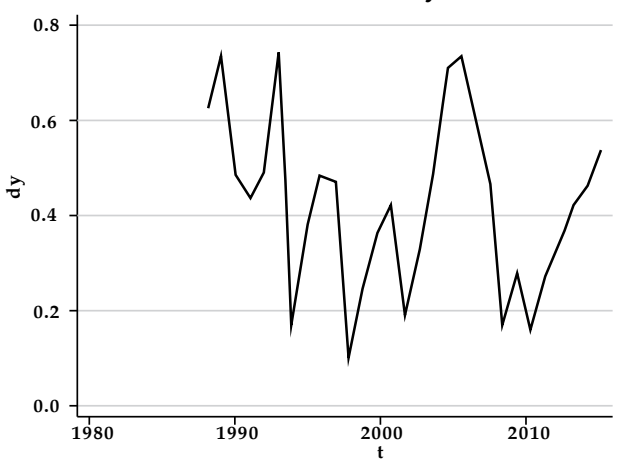

Source: Author's illustration.

Figure A5: Ln of primary enrolment, 1971 to 2014

Before stationary

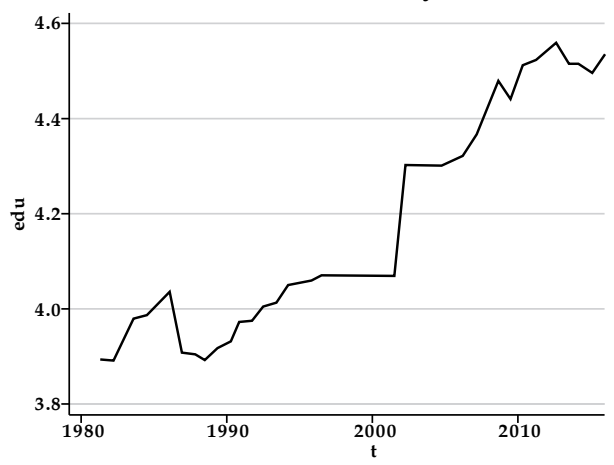

After stationary

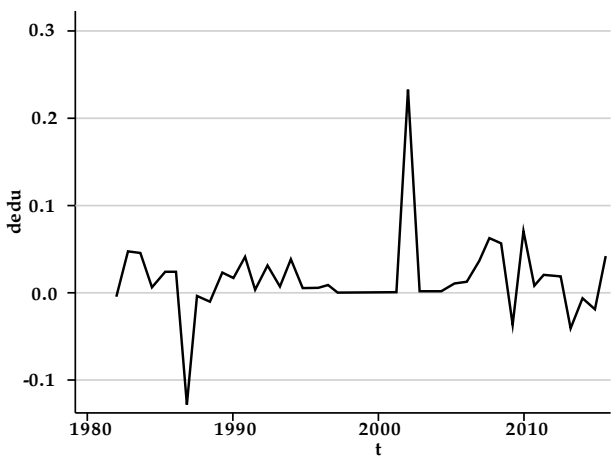

Source: Author's illustration. 
Figure A6: Ln of poverty gap, 1987 to 2012

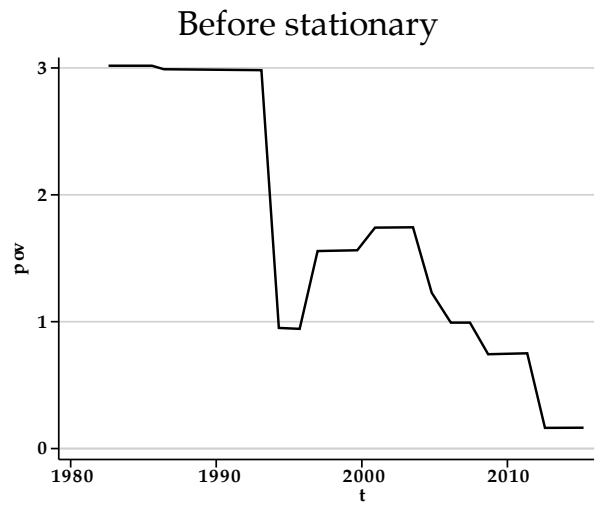

After stationary

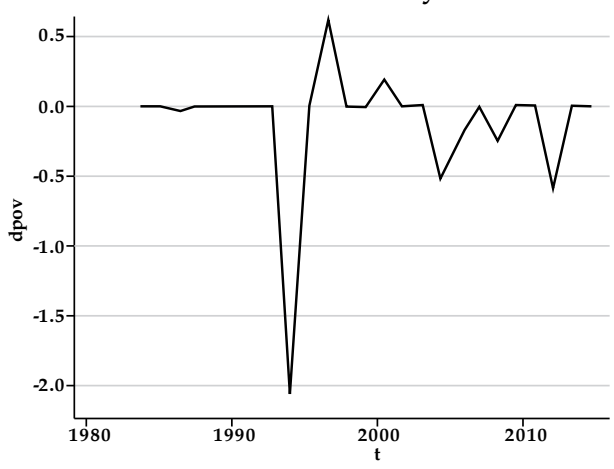

Source: Author's illustration.

Figure A7: Ln of GINI index, 1987 to 2010
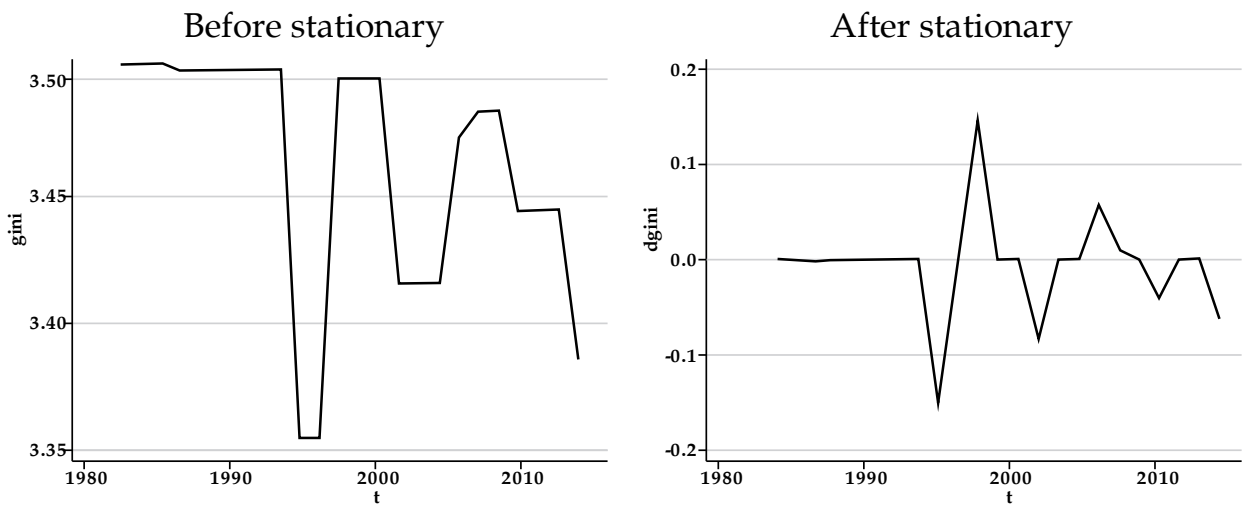

Source: Author's illustration. 